\title{
$\mathrm{H}_{2} \mathrm{O}_{2}$ Stimulates Cystic Fibrosis Transmembrane Conductance Regulator through an Autocrine Prostaglandin Pathway, Using Multidrug-Resistant Protein-4
}

\author{
Gregory E. Conner ${ }^{1,2 *}$, Pedro Ivonnet ${ }^{1 *}$, Murline Gelin ${ }^{1}$, Philip Whitney ${ }^{1}$, and Matthias Salathe ${ }^{1}$ \\ ${ }^{1}$ Division of Pulmonary, Allergy, Critical Care, and Sleep Medicine, Department of Medicine, and; ${ }^{2}$ Department of Cell Biology, Miller School of \\ Medicine, University of Miami, Miami, Florida
}

\begin{abstract}
Cystic fibrosis transmembrane conductance regulator (CFTR) activity is essential for the maintenance of airway surface liquid depth, and therefore mucociliary clearance. Reactive oxygen species, increased during inflammatory airway diseases, alter CFTR activity. Here, $\mathrm{H}_{2} \mathrm{O}_{2}$ levels in the surface liquid of normal human bronchial epithelial cultures differentiated at the air-liquid interface were estimated, and $\mathrm{H}_{2} \mathrm{O}_{2-}$ mediated changes in CFTR activity were examined. In Ussing chambers, $\mathrm{H}_{2} \mathrm{O}_{2}$-induced anion currents were sensitive to the CFTR inhibitors $\mathrm{CFTR}_{\text {inh }} 172$ and GlyH-101. These currents were absent in cells from patients with cystic fibrosis. Responses to greater than $500 \mu \mathrm{M} \mathrm{H} \mathrm{H}_{2}$ were transient. Cyclooxygenase inhibitors blocked the $\mathrm{H}_{2} \mathrm{O}_{2}$ response, as did EP1 and EP4 receptor antagonists. A multidrug-resistant protein (MRP) inhibitor and short hairpin RNA directed against MRP4 blocked $\mathrm{H}_{2} \mathrm{O}_{2}$ responses. EP1 and EP4 agonists mimicked $\mathrm{H}_{2} \mathrm{O}_{2}$ in both control and MRP4 knockdown cells. Thus, $\mathrm{H}_{2} \mathrm{O}_{2}$ activates the synthesis, export, and binding of prostanoids via EP4 and, interestingly, EP1 receptors in normal, differentiated human airway epithelial cells to activate cyclic adenosine monophosphate pathways that in turn activate CFTR channels in the apical membrane.
\end{abstract}

Keywords: MRP4; $\mathrm{H}_{2} \mathrm{O}_{2} ; \mathrm{CFTR}$; EP4; EP1

Effective airway clearance relies on the regulation of ciliary beat frequency (CBF), adequate airway surface liquid (ASL) volume, and correct mucus properties. Mucus hydration and thus the viscosity of mucus depend, in part, on the movement of water through the airway epithelium to the mucosal surface via the coordinated activities of ion channels. An important player in this regulation is the cystic fibrosis transmembrane conductance regulator (CFTR) that passes chloride (and other anions) while regulating the epithelial $\mathrm{Na}^{+}$channel to balance osmolarity (1). CFTR and CBF are both regulated through increases in cyclic adenosine monophosphate (cAMP) and protein kinase A activity (2-4). Thus, mediators that stimulate adenylyl cyclase are expected to result in improved airway clearance by increasing chloride secretion and $\mathrm{CBF}$.

(Received in original form April 1, 2013 and in final form May 6, 2013)

* These two authors contributed equally to this work.

This work was supported by National Institutes of Health grants HL-66125 (G.E.C.) and HL-60644 and HL-89399 (M.S.), Flight Attendant's Medical Research Institute grants 092061 (G.E.C.) and 103027 (M.S.), and the James and Esther King Biomedical Research Program (G.E.C.)

Correspondence and requests for reprints should be addressed to Matthias Salathe, M.D., Division of Pulmonary, Allergy, Critical Care, and Sleep Medicine, Department of Medicine, Miller School of Medicine, University of Miami, PO Box 016960, Miami, FL 33101. E-mail: msalathe@med.miami.edu

This article has an online supplement, which is accessible from this issue's table of contents at www.atsjournals.org

Am J Respir Cell Mol Biol Vol 49, Iss. 4, pp 672-679, Oct 2013

Copyright $\odot 2013$ by the American Thoracic Society

Originally Published in Press as 10.1165/rcmb.2013-01560C on June 6, 2013

Internet address: www.atsjournals.org

\section{CLINICAL RELEVANCE}

This study identifies new pathways by which hydrogen peroxide signals in airway epithelial cells. The signaling is beneficial at low hydrogen peroxide levels, but could be detrimental at high levels. This could have implications when treating patients with airway diseases.

Airway epithelia actively synthesize $\mathrm{H}_{2} \mathrm{O}_{2}$ via the nicotinamide adenine dinucleotide phosphate-reduced (NADPH) dual oxidases Duox1 and Duox2, as reviewed by Fischer (5), presumably for the use of the lactoperoxidase host defense against infection (6-9). Duox1 and Duox2 are regulated by cytokines (10-12) and bacterial products $(10,13,14)$ to increase $\mathrm{H}_{2} \mathrm{O}_{2}$ synthesis to high levels (10). Stimulation with interferon- $\gamma$ increased $\mathrm{H}_{2} \mathrm{O}_{2}$ synthesis levels 30 -fold when measured in air-liquid interface (ALI) cultures of normal human airway epithelial cells (10), leading to $10 \mu \mathrm{M} \mathrm{H}_{2} \mathrm{O}_{2}$ in washes used for assays. The experiments presented here address ASL $\mathrm{H}_{2} \mathrm{O}_{2}$ and show that it is present at high concentrations.

In addition to its role in stimulating lactoperoxidase host defense, $\mathrm{H}_{2} \mathrm{O}_{2}$ may also regulate the innate defense related to mucociliary clearance. In the bronchial submucosal adenocarcinoma cell line Calu-3, CFTR activity is increased by exposure of the airway epithelium to exogenous $\mathrm{H}_{2} \mathrm{O}_{2}(15,16)$. In cell lines, the effect of $\mathrm{H}_{2} \mathrm{O}_{2}$ on CFTR is reported to occur through increases in transmembrane adenylyl cyclase activity and through the activation of two $\mathrm{K}^{+}$channels (15), most likely KCNQ1 and KCNN4, which are located in the basolateral membrane. These channels are believed to provide a driving force for apical $\mathrm{Cl}^{-}$release $(17$, 18). Yet the mechanisms by which $\mathrm{H}_{2} \mathrm{O}_{2}$ leads to the activation of the cAMP pathway are not understood. Although both Calu-3 cells (19) and bovine tracheal epithelia (20) have been shown to respond to isoprostanes through the activation of prostanoid receptors, suggesting that the oxidative stress-induced formation of isoprostanes may be a mechanism by which $\mathrm{H}_{2} \mathrm{O}_{2}$ activates CFTR, findings in epithelial cell lines may not adequately reflect the processes relevant to the native human airway epithelium.

To study the $\mathrm{H}_{2} \mathrm{O}_{2}$-mediated activation of CFTR in primary human airway epithelia and examine the $\mathrm{H}_{2} \mathrm{O}_{2}$-mediated signaling cascade that leads to CFTR activation, we used redifferentiated normal human bronchial epithelial (NHBE) cell cultures and Ussing chambers to measure anion secretion in response to exogenous $\mathrm{H}_{2} \mathrm{O}_{2}$. These experiments showed that $\mathrm{H}_{2} \mathrm{O}_{2}$ stimulates cyclooxygenase $(\mathrm{COX})$ and downstream autocrine prostanoid effects via the EP4 and EP1 receptors (the EP1 receptor was not previously appreciated to be relevant in airway epithelial cells) that depend on the activity of the multidrugresistant protein-4 (MRP4). A novel model of activating cAMP production in differentiated NHBE cells is presented. 

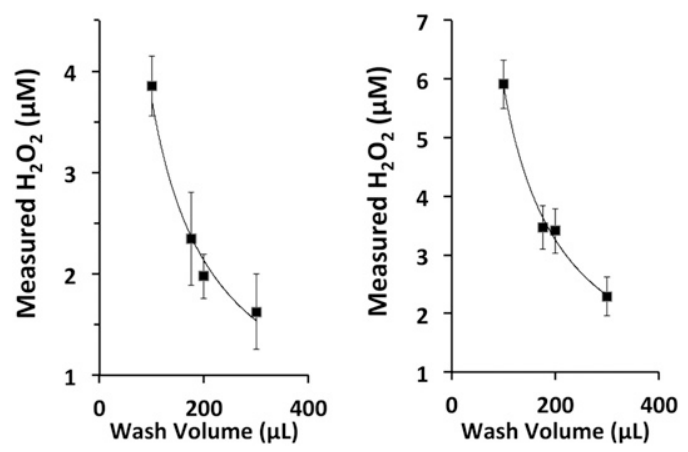

Figure 1. Dilution assays predict airway surface liquid (ASL) $\left[\mathrm{H}_{2} \mathrm{O}_{2}\right]$. Normal human bronchial epithelial (NHBE) cultures were stimulated with IFN- $\gamma$ for 48 hours to mimic inflammatory-related changes in dual oxidase-2 (Duox2) activity. Apical surfaces of triplicate cultures from two lung donors were incubated for 2 minutes with different volumes of Dulbecco's PBS and assayed for $\mathrm{H}_{2} \mathrm{O}_{2}$. Rates of $\mathrm{H}_{2} \mathrm{O}_{2}$ production were $3.3 \pm 0.2 \mathrm{pMoles} /$ minute $/ \mathrm{cm}^{2}$ (left) and $5.0 \pm 0.2 \mathrm{pMoles} /$ minute $/ \mathrm{cm}^{2}$ (right). Plots of $\left[\mathrm{H}_{2} \mathrm{O}_{2}\right]$ and wash volume are plotted and are fit to dilution curves with $\mathrm{R}^{2}>0.98$, suggesting that assays reflected the initial ASL $\mathrm{H}_{2} \mathrm{O}_{2}$ levels.

\section{MATERIALS AND METHODS}

\section{Cell Culture}

Human airway epithelial cells were obtained from organ donors whose lungs were rejected for transplant. Consent was obtained through the Life Alliance Organ Recovery Agency of the University of Miami, according to protocols approved by the Institutional Review Board. Epithelial cells from the lower trachea and upper bronchi were isolated as previously described $(21,22)$. Cystic fibrosis (CF) lungs were obtained from two patients undergoing lung transplantation, with appropriate consents approved by the Institutional Review Board. The genotypes of these lungs were $\triangle \mathrm{F} 508 / \mathrm{R} 347 \mathrm{P}$ and $\triangle \mathrm{F} 508 / \mathrm{D} 1152 \mathrm{H}$. ALI cultures were allowed to differentiate for at least 2 weeks before experimentation. All experiments were performed with datematched, passage-matched, and lung-matched control cultures.

\section{Chemicals}

Dulbecco's Modified Eagle's Medium, Ham's nutrient F-12, and Hanks' balanced salt solution were purchased from Gibco (Life Technologies, Grand Island, NY). GlyH-101 was obtained from Calbiochem (San Diego, CA). COX inhibitors and prostanoid receptor agonists and antagonists were acquired from Cayman Chemicals (Ann Arbor, MI). All other chemicals, unless otherwise stated, were purchased from Sigma-Aldrich (St. Louis, MO).

\section{Ussing Chambers}

Snapwell filters containing differentiated NHBE cells were rinsed with Krebs-Henseleit solution (KH), and then mounted in Ussing chambers (EasyMount Chambers; Physiologic Instruments, San Diego, CA) with $\mathrm{KH}$ in apical and basolateral chambers. $\mathrm{KH}$ consisted of $118 \mathrm{mM} \mathrm{NaCl}$, $25 \mathrm{mM} \mathrm{NaHCO}_{3}, 4.7 \mathrm{mM} \mathrm{KCl}, 1.2 \mathrm{mM} \mathrm{MgSO}_{4}, 1.2 \mathrm{mM} \mathrm{NaH}_{2} \mathrm{PO}_{4}, 1.2$ $\mathrm{mM} \mathrm{CaCl}$, and $5.5 \mathrm{mM}$ glucose, $\mathrm{pH} 7.35$ when gassed with $95 \% \mathrm{O}_{2} / 5 \%$ $\mathrm{CO}_{2}$. Solutions were maintained at $37^{\circ} \mathrm{C}$ by heated water jackets, and were continuously bubbled with a $95 \% \mathrm{O}_{2} / 5 \% \mathrm{CO}_{2}$ mixture. To monitor the short-circuit current $\left(\mathrm{I}_{\mathrm{SC}}\right)$, the transepithelial membrane potential was clamped at $0 \mathrm{mV}$ with a two-channel voltage clamp (model VCC MC2; Physiologic Instruments), using $\mathrm{Ag} / \mathrm{AgCl}$ electrodes in agar bridges. Signals were digitized and recorded with DAQplot software (VVI Software, College Station, PA) via a LabJack A/D converter (LabJack Corp., Lakewood, CO). The input resistance of each filter was measured by the application of 1-mV bipolar pulses of a 2-second duration. After the addition of amiloride, the $\mathrm{I}_{\mathrm{SC}}$ was allowed to stabilize, and then $\mathrm{H}_{2} \mathrm{O}_{2}$ was included in the apical or basolateral perfusate. Time scales were initialized at the time of mounting in the chamber. A dose-dependent increase in $\mathrm{I}_{\mathrm{SC}}$ was observed in response to $\mathrm{H}_{2} \mathrm{O}_{2}$. To explore the mechanisms responsible for this change in $\mathrm{I}_{\mathrm{SC}}$, cultures were incubated with pharmacological agents for 20-50 minutes before and during exposure to $\mathrm{H}_{2} \mathrm{O}_{2}$.
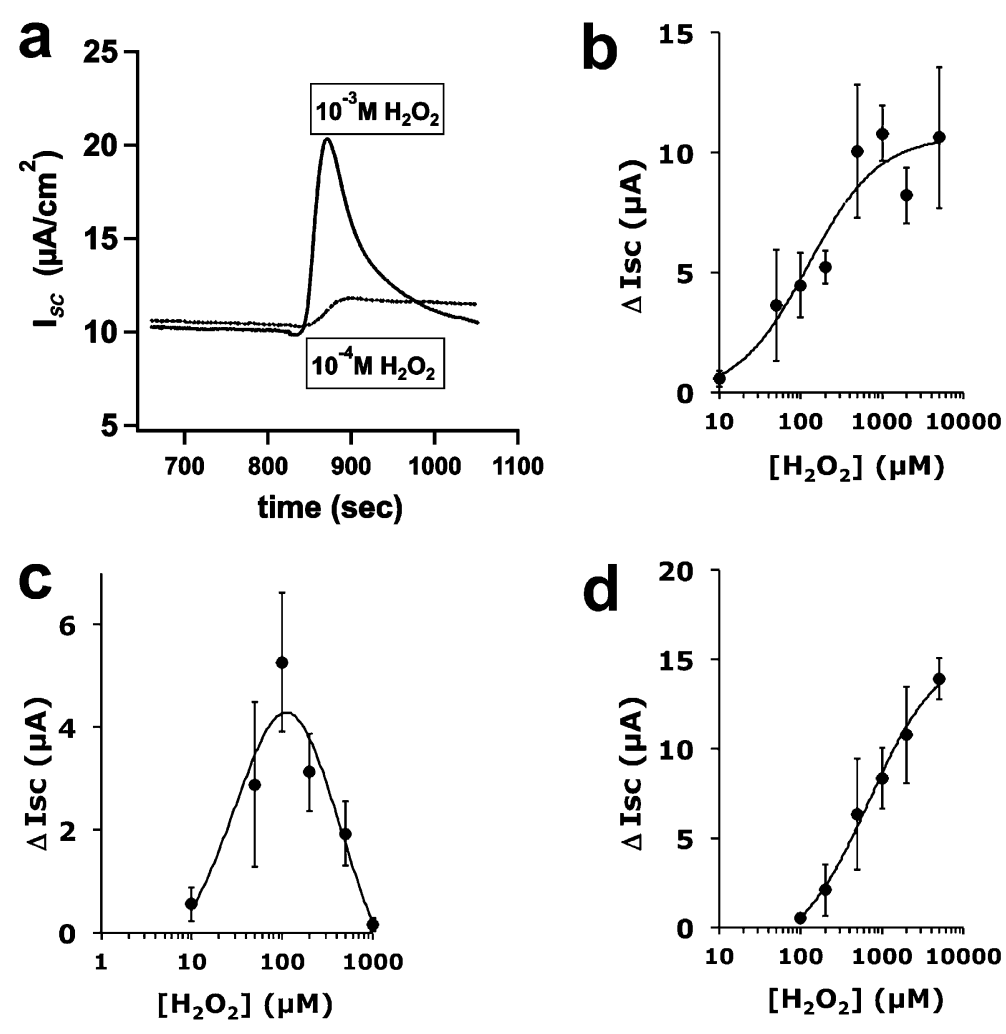

Figure 2. $\mathrm{H}_{2} \mathrm{O}_{2}$ stimulates apical anion secretion by primary NHBE cells cultured at the air-liquid interface (ALI). Fully differentiated NHBE cells were mounted in Ussing chambers in Krebs-Henseleit $(\mathrm{KH})$ buffer and stimulated with $\mathrm{H}_{2} \mathrm{O}_{2}$ in either the apical $(a-c)$ or basolateral $(\mathrm{BL})(d)$ chamber. High concentrations $(1 \mathrm{mM})$ resulted in a transient increase in the short-circuit current $\left(\mathrm{I}_{\mathrm{SC}}\right)$ ( $a$, solid trace), whereas lower concentrations resulted in a sustained increase in $\mathrm{I}_{\mathrm{SC}}$ ( $a$, dashed trace, and $c$ ). (b) Peak $\mathrm{I}_{\mathrm{SC}}$ increased with increasing apical $\left[\mathrm{H}_{2} \mathrm{O}_{2}\right]$ to $1 \mathrm{mM}$. Sustained $\mathrm{I}_{\mathrm{SC}}$ (at 4 minutes) revealed a bellshaped curve. (d) Peak $\mathrm{I}_{\mathrm{SC}}$ increased less when $\mathrm{H}_{2} \mathrm{O}_{2}$ was added to the $\mathrm{BL}$ compartment. All experiments contained 10 $\mu \mathrm{M}$ amiloride in the apical chamber. All values represent means \pm SEMs ( $n=3-20$ lung donors per point). 


\section{Data Analysis}

The maximum change in $\mathrm{I}_{\mathrm{SC}}$ after stimulation was normalized to baseline values obtained after the addition of amiloride and the other inhibitors used. Replicate cultures from each lung donor and then all donors were averaged to give mean values for the maximum. Sustained $\mathrm{I}_{\mathrm{SC}}$ was measured 4 minutes after the addition of $\mathrm{H}_{2} \mathrm{O}_{2}$. When multiple treatments were compared, changes were expressed as a fraction of date-matched and lung-matched control samples. Mean values were compared by one-way ANOVA, and if significant differences were obtained, mean values were then compared by the Tukey-Kramer honestly significant difference test. If the means were not normal, the Wilcoxon test was used (JMP Software; SAS, Cary, NC). $\mathrm{EC}_{50}$ values were calculated according to the nonlinear regression fit of the log of agonist concentrations versus $\Delta \mathrm{I}_{\mathrm{SC}}$ responses.

\section{RESULTS}

\section{$\mathrm{H}_{2} \mathrm{O}_{2}$ Accumulates in ASL}

We previously showed that IFN- $\gamma$-stimulated NHBE cells cultured at the ALI produced high levels of $\mathrm{H}_{2} \mathrm{O}_{2}$, at up to 5-10 $\mu \mathrm{M}$ in apical washes used for assay (10). Thus, much higher concentrations exist in the ASL before washes were used to collect samples (dilution). To assess whether the volume of the apical washes influenced the $\left[\mathrm{H}_{2} \mathrm{O}_{2}\right]$ detected and whether assay values could be extrapolated to ASL concentrations, triplicate ALI cultures on 12-mm culture inserts from two individual lung donors were washed with four different volumes of PBS and assayed for $\mathrm{H}_{2} \mathrm{O}_{2}$ (detailed methods are provided in the online supplement). The $\left[\mathrm{H}_{2} \mathrm{O}_{2}\right]$ detected decreased with higher wash volumes, almost perfectly fitting a dilution curve (Figure 1). Therefore, the assays directly reflect the initial $\left[\mathrm{H}_{2} \mathrm{O}_{2}\right]$ in ASL. On NHBE cells cultured at the ALI, the ASL is reported to be approximately $12 \mu \mathrm{m}$ deep (23), corresponding to a surface volume of approximately $6 \mu \mathrm{l}$, because of the meniscus at the edge of the culture surface (24). Using $6 \mu l$ as a total volume of the apical compartment, the data predict that the ASL $\left[\mathrm{H}_{2} \mathrm{O}_{2}\right]$ for these donors would be 32 and $64 \mu \mathrm{M}$. The extrapolation of single-volume assays from IFN- $\gamma$-treated cultures of other lung donors showed values as high as $150 \mu \mathrm{M}$. Thus, $\mathrm{H}_{2} \mathrm{O}_{2}$ accumulates to levels substantially higher than those generally believed to be present in viable cell cultures as well as in tissues, and could exert a variety of effects not previously appreciated.

\section{Effect of $\mathrm{H}_{2} \mathrm{O}_{2}$ on $\mathrm{I}_{\mathrm{sc}}$}

CFTR-mediated epithelial anion secretion has been shown to occur in response to exogenous $\mathrm{H}_{2} \mathrm{O}_{2}$ in several cell lines used as models of airway epithelia $(15,16,25)$. To clarify the effects of different amounts of $\left[\mathrm{H}_{2} \mathrm{O}_{2}\right]$ on anion secretion by cells most closely resembling the native human airway epithelium (26) and to study the mechanism of $\mathrm{H}_{2} \mathrm{O}_{2}$ actions, NHBE cultures fully differentiated at the ALI were mounted in Ussing chambers and exposed to increasing concentrations of either apically or basolaterally added $\mathrm{H}_{2} \mathrm{O}_{2}$. In $\mathrm{KH}$ buffer, the initial transepithelial voltage and resistance were $-7.3 \pm 0.5 \mathrm{mV}$ (mean $\pm \mathrm{SEM}, n=459$ cultures from 50 lung donors) and $806 \pm 64 \Omega / \mathrm{cm}^{2}$ (mean \pm SEM, $n=395$ cultures from 32 lung donors), respectively. After clamping to $0 \mathrm{mV}$, treatment with $10 \mu \mathrm{M}$ amiloride (epithelial sodium channel blocker) decreased the basal $\mathrm{I}_{\mathrm{SC}}$ from $10.7 \pm 0.4 \mu \mathrm{A} / \mathrm{cm}^{2}$ to $7.8 \pm 0.3 \mu \mathrm{A}$ (mean \pm SEM, $n=219$ cultures from 40 lung donors, $P<0.05$ ).

Apical exposure to $\mathrm{H}_{2} \mathrm{O}_{2}$ resulted in an increased, outward $\mathrm{I}_{\mathrm{SC}}$ that was amiloride-insensitive. Thus, all further experiments were performed in the presence of $10 \mu \mathrm{M}$ amiloride to block epithelial sodium channel. Both the amplitude and duration of the $\mathrm{I}_{\mathrm{SC}}$ increase were dependent on the $\left[\mathrm{H}_{2} \mathrm{O}_{2}\right]$ (Figure 2). At high $\mathrm{H}_{2} \mathrm{O}_{2}$ concentrations $(>500 \mu \mathrm{M})$, the change in $\mathrm{I}_{\mathrm{SC}}\left(\Delta \mathrm{I}_{\mathrm{SC}}\right)$ was transient, whereas $\Delta \mathrm{I}_{\mathrm{SC}}$ was sustained for longer periods $(>20 \mathrm{~min})$ at lower $\mathrm{H}_{2} \mathrm{O}_{2}$ concentrations (Figure 2a). As $\mathrm{H}_{2} \mathrm{O}_{2}$ concentrations increased, the peak $\mathrm{I}_{\mathrm{SC}}$ amplitude increased (Figure 2b), whereas the plateau of sustained $\Delta \mathrm{I}_{\mathrm{SC}}\left(4 \mathrm{~min}\right.$ after $\mathrm{H}_{2} \mathrm{O}_{2}$ addition) was maximal at around $100 \mu \mathrm{M} \mathrm{H}_{2} \mathrm{O}_{2}$ (Figure 2c), suggesting that $\mathrm{H}_{2} \mathrm{O}_{2}$ stimulated peak $\mathrm{I}_{\mathrm{SC}}$ in a concentration-dependent manner. On the other hand, a plateau was only sustained at lower, possibly more physiological $\left[\mathrm{H}_{2} \mathrm{O}_{2}\right]$, whereas higher concentrations returned to baseline by 4 minutes. Treatment with catalase completely blocked the $\mathrm{H}_{2} \mathrm{O}_{2}$ responses (data not shown).

Basolateral stimulation with $\mathrm{H}_{2} \mathrm{O}_{2}$, which was also sensitive to CFTR inhibitors, required higher concentrations to induce
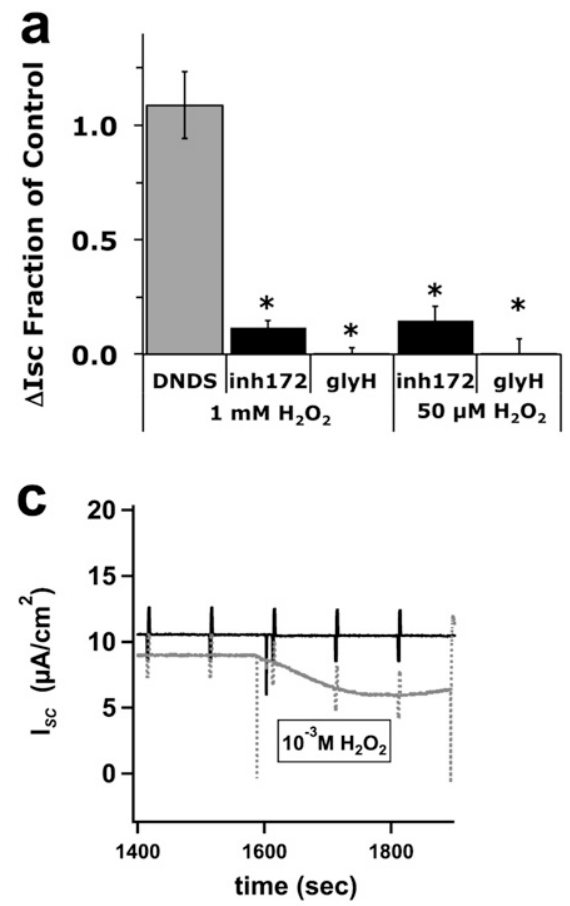
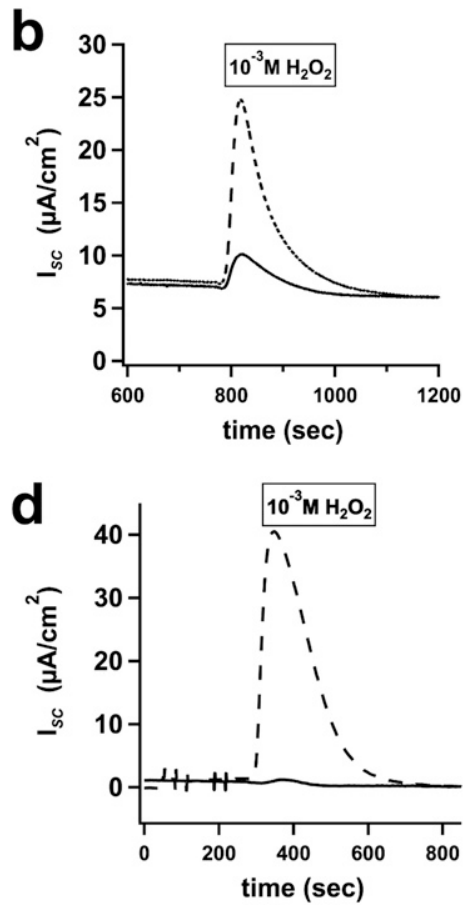

Figure 3. Functional cystic fibrosis transmembrane conductance regulator (CFTR) is needed for $\mathrm{H}_{2} \mathrm{O}_{2}$-induced $\Delta \mathrm{I}_{\mathrm{SC}}$. NHBE cells, fully differentiated at the ALI, were mounted in Ussing chambers, and treated apically with amiloride, followed by either apical 4,4'-dinitrostilbene$2,2^{\prime}$-disulfonic acid $(100 \mu \mathrm{M}, n=4$ cultures from three

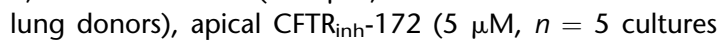
from four lung donors), or apical GlyH-101 (10 $\mu \mathrm{M}, n=8$ cultures from seven lung donors), and then stimulation with either $1 \mathrm{mM}$ or $50 \mu \mathrm{M} \mathrm{H}_{2} \mathrm{O}_{2}$ in the apical compartment. (a) CFTR inh -172 and GlyH-101 significantly blocked the $\mathrm{H}_{2} \mathrm{O}_{2}$-induced $\Delta \mathrm{I}_{\mathrm{SC}}$ at $1 \mathrm{mM}$. CFTR inh $^{-172(5 \mu \mathrm{M}, n=}$ 8 cultures from five lung donors) and GlyH-101 (10 $\mu \mathrm{M}$, $n=3$ lung donors) also blocked responses at $50 \mu \mathrm{M}(a)$. (b) A representative trace with CFTR $_{\text {inh }}-172(5 \mu \mathrm{M}$, solid line) and control trace (dotted line) at $1 \mathrm{mM} \mathrm{H}_{2} \mathrm{O}_{2}$. Fully differentiated cystic fibrosis bronchial epithelial (CFBE) culture did not increase $\mathrm{I}_{\mathrm{SC}}$ after apical $1 \mathrm{mM} \mathrm{H}_{2} \mathrm{O}_{2}$ treatment (c, bottom trace in gray). (c) CFBE not treated with $\mathrm{H}_{2} \mathrm{O}_{2}$ (top trace). (d) A representative trace with GlyH-101 (10 $\mu \mathrm{M}$, solid line) and a control trace (dotted line) at $1 \mathrm{mM}$ $\mathrm{H}_{2} \mathrm{O}_{2}$. Values represent means \pm SEMs. ${ }^{*} P<0.05$. 
similar increases in $\mathrm{I}_{\mathrm{SC}}$ when compared with apical $\mathrm{H}_{2} \mathrm{O}_{2}$ stimulation (compare Figure $2 \mathrm{~b}$ with Figure 2d), suggesting a difference in $\mathrm{H}_{2} \mathrm{O}_{2}$ action at the apical membrane versus the basolateral membrane. The addition of $1 \mathrm{mM} \mathrm{H}_{2} \mathrm{O}_{2}$ to the apical surface induced a transient $\Delta \mathrm{I}_{\mathrm{SC}}$, whereas the addition of the same $\mathrm{H}_{2} \mathrm{O}_{2}$ concentration to the basolateral side induced a sustained $\Delta \mathrm{I}_{\mathrm{SC}}$ with an amplitude greater than the highest mean sustained response obtained with any apical $\left[\mathrm{H}_{2} \mathrm{O}_{2}\right]$. Eliciting a transient $\Delta \mathrm{I}_{\mathrm{SC}}$ using basolateral $\mathrm{H}_{2} \mathrm{O}_{2}$ required a concentration greater than $2 \mathrm{mM}$ (not shown).

Because lower $\left[\mathrm{H}_{2} \mathrm{O}_{2}\right]$ did not show a transient $\mathrm{I}_{\mathrm{SC}}$ response, the consumption of $\mathrm{H}_{2} \mathrm{O}_{2}$ was probably not responsible for the transient responses at high concentrations. To confirm this, buffer in the apical chamber was assayed for $\mathrm{H}_{2} \mathrm{O}_{2}$, and more than $70 \%$ remained after the return of $\mathrm{I}_{\mathrm{SC}}$ to baseline. This was also confirmed by the transfer of the apical buffer to a new culture in a separate chamber that responded by increasing $\mathrm{I}_{\mathrm{SC}}$ as expected for the measured $\left[\mathrm{H}_{2} \mathrm{O}_{2}\right]$ (see Figure E1 in the online supplement). In addition, after stimulation with lower $\left[\mathrm{H}_{2} \mathrm{O}_{2}\right](<300 \mu \mathrm{M})$ followed by exchange to fresh $\mathrm{KH}$, cultures responded to a second $\mathrm{H}_{2} \mathrm{O}_{2}$ treatment, although with some degree of attenuation. Higher $\left[\mathrm{H}_{2} \mathrm{O}_{2}\right](>500 \mu \mathrm{M})$ greatly diminished or completely obliterated any response subsequent to the first stimulation (data not shown). Thus, high $\left[\mathrm{H}_{2} \mathrm{O}_{2}\right]$ appeared to alter a component needed for anion transport.

Together, these data differed from those in previous reports using cell lines, in that high $\mathrm{H}_{2} \mathrm{O}_{2}$ concentrations in primary, fully differentiated human airway epithelial cells led to transient changes in $\mathrm{H}_{2} \mathrm{O}_{2}$-induced CFTR anion conductance $(15,16)$, similar to the results of Dazy and colleagues (25) using hydroxyl radicals. To assess the role of the hydroxyl radical, cultures were pretreated with deferoxamine and stimulated with $\mathrm{H}_{2} \mathrm{O}_{2}$ in the presence of deferoxamine. No reduction was evident in transient peak amplitude, suggesting that hydroxyl radicals were not responsible for the observed $\mathrm{I}_{\mathrm{SC}}$ changes (data not shown).

Pretreatment or posttreatment with apical $5 \mu \mathrm{M}$ CFTR $_{\text {inh }}-172$ or $10 \mu \mathrm{M}$ GlyH-101 drastically attenuated the $\mathrm{H}_{2} \mathrm{O}_{2}$-induced responses, whereas apical $100 \mu \mathrm{M}$ 4,4'-dinitrostilbene-2,2' -disulfonic acid (inhibitor of $\mathrm{Cl}^{-}$channels other than CFTR in intact cells, including calcium-activated chloride channels) exerted no effect (Figure 3). These results suggest that the response to $\mathrm{H}_{2} \mathrm{O}_{2}$ depended on CFTR and not another $\mathrm{Cl}^{-}$channel. This was confirmed by an examination of $\mathrm{CF}$ bronchial epithelial cell cultures that demonstrated no increase in the $\mathrm{H}_{2} \mathrm{O}_{2}$-induced $\mathrm{I}_{\mathrm{SC}}$, confirming that the responses were attributable to the stimulation of CFTR activity and not other $\mathrm{Cl}^{-}$channels (Figure 3c). The sustained $\mathrm{I}_{\mathrm{SC}}$ responses seen at lower concentrations of $\mathrm{H}_{2} \mathrm{O}_{2}$ were identically sensitive to $\mathrm{CFTR}_{\text {inh }}-172$ and GlyH-101, suggesting that the lower $\left[\mathrm{H}_{2} \mathrm{O}_{2}\right]$ seen in cell cultures (Figure 1) also induced CFTR-dependent $\mathrm{I}_{\mathrm{SC}}$ changes $\left(50 \mu \mathrm{M} \mathrm{H}_{2} \mathrm{O}_{2}\right.$; Figure $\left.3 \mathrm{a}\right)$.

\section{Role of COX in Hydrogen Peroxide Stimulation of $\mathrm{I}_{\mathrm{SC}}$}

Previous studies showed that isoprostanoids, formed by nonenzymatic peroxidation, activated the $\mathrm{Cl}^{-}$secretion response in bovine tracheal epithelial cultures and Calu-3 cells $(19,20)$. In contrast, we found that $\mathrm{H}_{2} \mathrm{O}_{2}$ stimulated $\mathrm{COX}$ activity, resulting in prostanoid formation, as previously described in other cells (27). COX inhibitors were examined for their ability to block $\mathrm{H}_{2} \mathrm{O}_{2}$-induced $\Delta \mathrm{I}_{\mathrm{SC}}$. The COX-1 inhibitor SC-560 $(0.5 \mu \mathrm{M})$ and the specific COX-2 inhibitor ns398 $(20 \mu \mathrm{M})$ blocked $\mathrm{H}_{2} \mathrm{O}_{2}$ responses (Figure 4). Although SC-560 is highly selective for COX-1 in cell-free assays, it has been shown to lack specificity relative to COX-2 when used with intact cells (28). Thus, the data support the idea that COX-2 and perhaps COX-1 activity
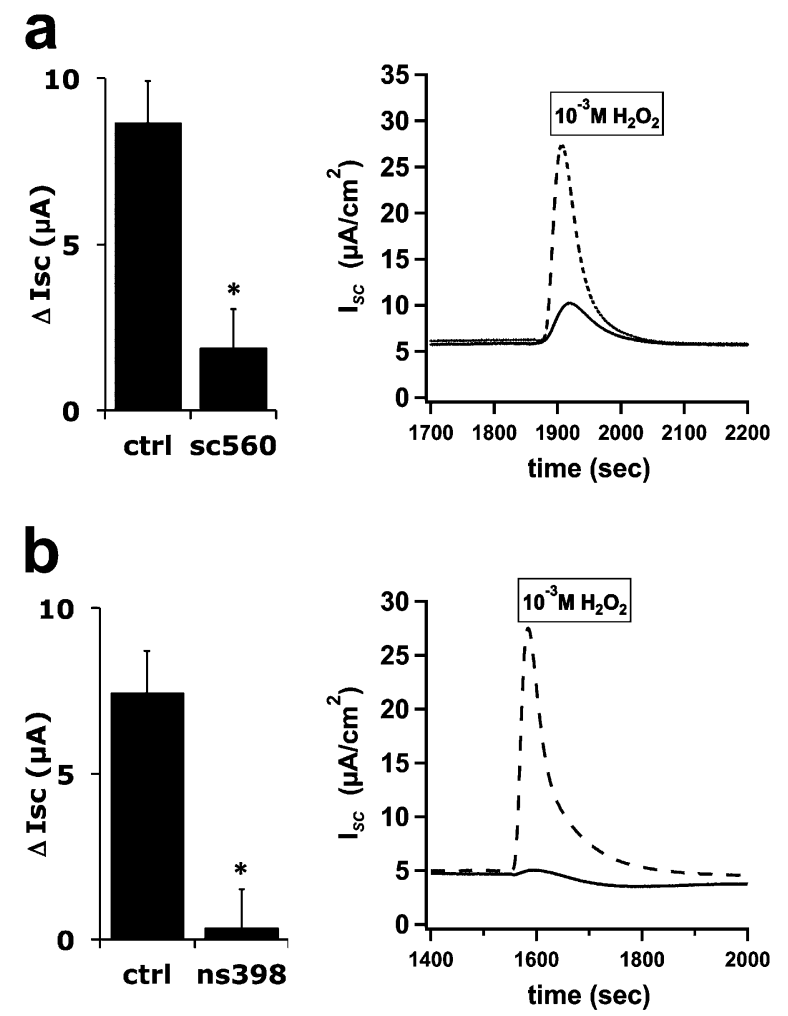

Figure 4. $\mathrm{H}_{2} \mathrm{O}_{2}$ activation of cyclooxygenase (COX) contributes to anion secretion. Fully differentiated NHBE cultures were mounted in Ussing chambers and treated with amiloride, followed by either the COX-1 inhibitor SC-560 (500 nM, $n=9$ cultures from seven donors, a) or the COX-2 inhibitor ns $398(20 \mu \mathrm{M}, n=8$ cultures from eight donors, $b$ ) in the apical and $\mathrm{BL}$ compartments, and then stimulated with $1 \mathrm{mM} \mathrm{H}_{2} \mathrm{O}_{2}$ apically. Representative $\mathrm{I}_{\mathrm{SC}}$ traces show inhibitortreated (solid) and control (ctrl; dotted) cultures. Addition of the COX inhibitors SC-560 and ns398 blocked the $\mathrm{H}_{2} \mathrm{O}_{2}$ response. Values represent means \pm SEMs. ${ }^{*} P<0.05$.

is required, and that an autocrine prostanoid pathway is involved in the effects of $\mathrm{H}_{2} \mathrm{O}_{2}$ in fully differentiated NHBE cells. Because the specific inhibitor for COX-2 (ns398) blocked virtually all of the response, these results were also in contrast with previous reports using the Calu-3 cell line and showing that COX-1 was primarily responsible for the effects of $\mathrm{H}_{2} \mathrm{O}_{2}$ (29). To confirm a role for prostanoid signaling and to assess which prostanoid receptor may be mediating the effect, receptor antagonists were used (Figure 5a). The EP1 prostanoid receptor antagonist SC-19220 (20 $\mu \mathrm{M})$ inhibited approximately $75 \%$ of the $\mathrm{H}_{2} \mathrm{O}_{2}$ response, whereas the EP4 antagonist AH23848 (10 $\mu \mathrm{M})$ blocked a larger fraction. Antagonists of other prostanoid receptors did not significantly block the $\mathrm{H}_{2} \mathrm{O}_{2}$ response, namely, DP1 antagonist MK-0524 (5 nM), TP antagonist BM-567 (25 $\mathrm{nM})$, IP antagonist Cay-10449 (30 nM), and FP antagonist AL-8810 (3 $\mu \mathrm{M})$. Interestingly, the specific DP2 antagonist, Cay-10471 (10 nM), stimulated $\mathrm{H}_{2} \mathrm{O}_{2}$ responses nearly twofold (data not shown), suggesting a complex regulation of prostanoid pathways in response to $\mathrm{H}_{2} \mathrm{O}_{2}$. To further confirm the role of EP1 and EP4 in the $\mathrm{H}_{2} \mathrm{O}_{2}$ stimulation of CFTR activity, the EP1 agonist 17-phenyl trinor prostaglandin $\mathrm{E}_{2}\left(\mathrm{PGE}_{2}\right)(30)$ or the EP4 agonist Cay-10598 (31) was used to stimulate NHBE cultures. Examples of traces are shown in Figure E2. Doseresponse curves showed $\mathrm{EC}_{50}$ values (Figures $5 \mathrm{~b}$ and $5 \mathrm{c}$ ) within the published ranges used for stimulation by 17 phenyl trinor $\mathrm{PGE}_{2}(87 \mathrm{nM})$ (32-35) and Cay-10598 (61 nM) (36). Stimulation 


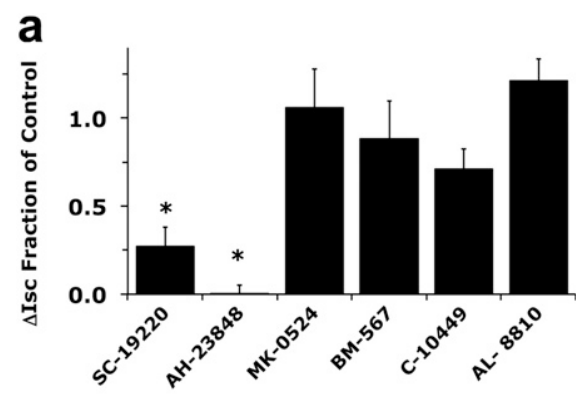

b

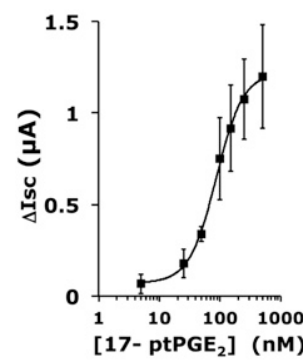

C

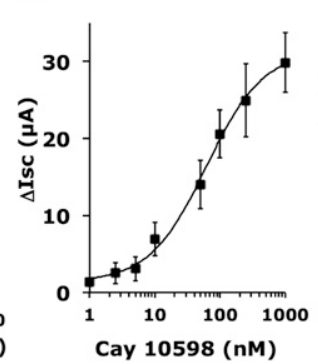

f

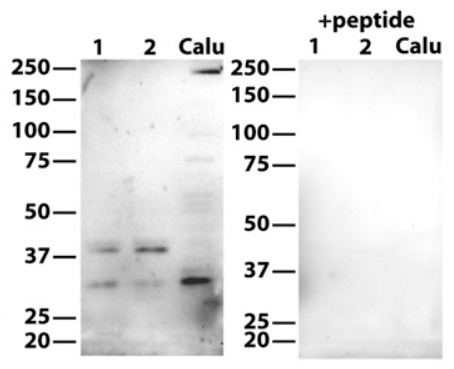

Figure 5. Role of prostanoid signaling in $\mathrm{H}_{2} \mathrm{O}_{2}$-induced $\mathrm{I}_{\mathrm{SC}}$ responses. Fully differentiated NHBE cultures were mounted in Ussing chambers and treated with amiloride, followed by receptor agonists and/or antagonists in the apical and basolateral (BL) compartments (see RESULTS for target receptors and concentrations used), and then stimulation with $1 \mathrm{mM} \mathrm{H}_{2} \mathrm{O}_{2}$. (a) The addition of EP1 (SC-19220) and EP4 (AH23848) antagonists blocked the $\mathrm{H}_{2} \mathrm{O}_{2}$ response ( $n=4-9$ lung donors). ${ }^{*} P<0.05$, compared with matched control samples. See the text for details of other antagonists. (b) Responses to 17-phenyl trinor prostaglandin $\mathrm{E}_{2}\left(\mathrm{PGE}_{2}\right)$ (17-ptPGE 2 ; an EP1 agonist) predict an $\mathrm{EC}_{50}$ value of $87 \mathrm{nM}$. (c) Responses to Cay10598 (an EP4 agonist) predict an $\mathrm{EC}_{50}$ of $61 \mathrm{nM}$. For $b$ and $c$, each point represents the means $\pm \operatorname{SEM}(n=$ 4-11 lung donors). (d) SC-51322 (an EP1 antagonist) partly inhibited the $\mathrm{H}_{2} \mathrm{O}_{2}$-stimulated $\mathrm{I}_{\mathrm{SC}}$, with an $\mathrm{IC}_{50}$ of $50 \mathrm{nM}$ (95\% confidence limit $= \pm 2 \mathrm{nM}, n=3-8$ lung donors each point). A Western blot of NHBE from three lung donors with anti-EP4 antibodies (e) and a Western blot of NHBE from two lung donors and of Calu- 3 cells with anti-EP1 antibodies ( $f$ ) showed the expression of bands at expected molecular sizes. EP1 antibody antigenic peptide blocked the labeling of EP1 bands, including the lower molecular mass band that is predominant in Calu-3 cells and less abundant in NHBE cultures.

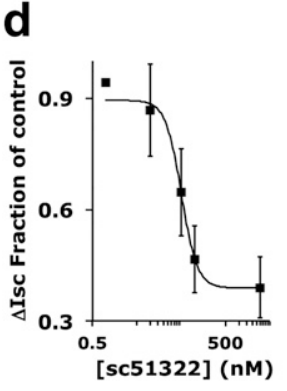

by either agonist was blocked by $\mathrm{CFTR}_{\text {inh }}-172$ (not shown). Higher concentrations of 17 phenyl trinor $\mathrm{PGE}_{2}$ further stimulated anion currents with an apparent $\mathrm{EC}_{50}$ in the low micromolar range, suggesting that this compound also stimulated other receptors present in NHBE cells with a lower affinity. Based on the relative responses to the EP1 and EP4 antagonists, stimulation of the EP4 receptors apparently leads to larger changes in anion current compared with the stimulation of EP1 receptors, reflecting the relative inhibition of the $\mathrm{H}_{2} \mathrm{O}_{2}$ response by antagonists.

Because a role for EP1 has not been previously described in bronchial epithelia, because the EP4 antagonist inhibited a larger fraction of $\mathrm{H}_{2} \mathrm{O}_{2}$ stimulation, and because 17 phenyl trinor $\mathrm{PGE}_{2}$ is not highly specific for EP1, the potency of the highly specific EP1 antagonist (SC-51322) on $\mathrm{H}_{2} \mathrm{O}_{2}$ stimulation was measured. SC-51322 partly blocked the $\mathrm{H}_{2} \mathrm{O}_{2}$-stimulated $\mathrm{I}_{\mathrm{SC}}$, with an apparent $\mathrm{IC}_{50}$ of $50 \mathrm{nM}$ (Figure $5 \mathrm{~d}$ ), comparable to published values $(37,38)$, further supporting that EP1 contributes to the $\mathrm{H}_{2} \mathrm{O}_{2}$ response.

Western blots were used to confirm the expression of EP4 (Figure 5e) and EP1 (Figure 5f) protein in multiple lung donors. A single band corresponding to the expected EP4 molecular mass was evident. Comparison of the EP4 signal to actin suggested that different levels of EP4 were expressed in three lung donors (Figure E4). EP1 antibodies showed two immunoreactive bands, one at the expected size of approximately $42 \mathrm{kD}$, and a second, smaller species of approximately $34 \mathrm{kD}$, possibly representing a proteolytic fragment, because no smaller splice variants have been reported. The relative amounts of the two species varied between lung donors, and the lower band was the only form visible in the Calu-3 cell line that has been used by others to study $\mathrm{H}_{2} \mathrm{O}_{2}$-stimulated anion currents. The preincubation of antibody with the antigenic peptide showed that both forms were specifically recognized by the antibodies. Thus, the data demonstrated that both the EP1 and EP4 receptors are present in NHBE cells and activate CFTR.

Prostanoid release from cells required for receptor activation can occur in other cells through MRP4 (39). MK571, a broadspecificity inhibitor of MRPs, blocked the $\mathrm{H}_{2} \mathrm{O}_{2}$-induced release of $\mathrm{PGE}_{2}$ (Figure E3b) and blocked $\mathrm{H}_{2} \mathrm{O}_{2}$-stimulated $\Delta \mathrm{I}_{\mathrm{SC}}$ changes (Figure 6a) when used at $20 \mu \mathrm{M}$, suggesting that MRP4 may play an important role. Conversely, MK571 at 1 $\mu \mathrm{M}$, which is also a cysteinyl leukotriene antagonist at low concentrations $\left(K_{\mathrm{i}} \leqslant 2 \mathrm{nM}\right)$, exerted no effect (not shown), suggesting that its activity as a cysteinyl leukotriene antagonist was not responsible for the observed effect. MK571 also blocked responses to lower concentrations of $\mathrm{H}_{2} \mathrm{O}_{2}$ (data not shown). Quantitative PCR showed that, compared with glyceraldehyde 3-phosphate dehydrogenase, MRP4 is expressed in these differentiated NHBE cells cultured at the ALI at a level in the same range as CFTR (Figure 6b). To confirm the role of MRP4 in $\mathrm{H}_{2} \mathrm{O}_{2}$-induced CFTR activation, undifferentiated NHBE cultures were infected with a lentivirus expressing short hairpin RNA (shRNA) directed at MRP4 (see the online supplement for lentivirus methods). After redifferentiation, $\mathrm{H}_{2} \mathrm{O}_{2}$-stimulated anion secretion was reduced (Figure $6 \mathrm{c}$ ) by an amount equivalent to the reduction of MRP4 mRNA expression as assessed by quantitative PCR (Figure 6d). Because MRP4 has been shown to interact with CFTR in mouse intestinal epithelia (40), MRP4 knockdown cultures were stimulated with forskolin or EP4 
a
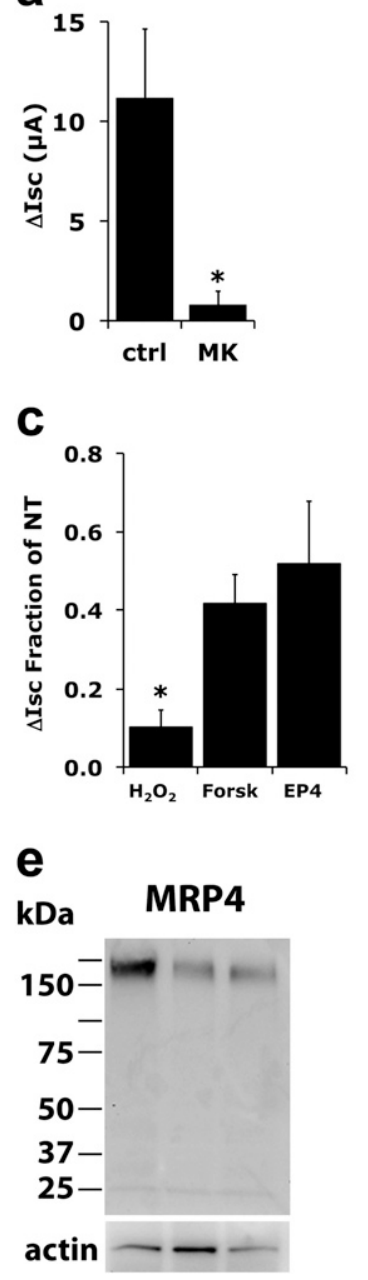

Figure 6. Multidrug-resistant protein-4 (MRP4) mediates the export of prostanoids. (a) Fully differentiated NHBE cultures were mounted in Ussing chambers and treated with amiloride, followed by $20 \mu \mathrm{M}$ MK571, an inhibitor of MRP transporters, and stimulated with $1 \mathrm{mM}$ $\mathrm{H}_{2} \mathrm{O}_{2}$. MK571 significantly inhibited $\mathrm{H}_{2} \mathrm{O}_{2}$ responses $(n=4$ cultures from four lung donors, $P<0.05$ ). (b) To confirm that MRP4 is expressed in differentiated NHBE cells, RNA from three lung donors was assessed for CFTR and MRP4 mRNA expression by TaqMan assays. MRP4 was expressed at a level similar to that of CFTR. (c) Differentiated NHBE cultures infected with either MRP4 or nontargeted (NT) short hairpin RNA (shRNA) expressing lentiviruses were assayed for their $I_{\mathrm{SC}}$ response to $\mathrm{H}_{2} \mathrm{O}_{2}$, forskolin, and Cay-10598 (an EP4 agonist). Cells infected with MRP4 shRNA lentivirus showed a large reduction of response to $\mathrm{H}_{2} \mathrm{O}_{2}$, whereas the responses to forskolin and Cay-10598 were reduced to lesser degree and were statistically significantly different, compared with $\mathrm{H}_{2} \mathrm{O}_{2}$ (all $P<0.05$, compared with NT; $n=4-8$ cultures from 4-5 lung donors). (d) Quantitative PCR of nontargeted (NT) and MRP4 shRNA (KD)-expressing cells showed a reduction in MRP4 mRNA ( $n=5$ cultures from four lung donors, $P<0.05$ ), equivalent to the reduction of $\mathrm{H}_{2} \mathrm{O}_{2}$ response seen in $c$. Values represent means \pm SEMs. ${ }^{*} P<0.05$. (e) Western blot analyses of three lung donors demonstrated a single species migrating at the expected MRP4 molecular mass. Comparison with actin suggested variation in MRP4 expression between donors.

agonists to confirm the signaling pathways that activate CFTR remained intact (Figure 6c). Although both forskolin-stimulated $\mathrm{I}_{\mathrm{SC}}$ and EP4 agonist-stimulated $\mathrm{I}_{\mathrm{SC}}$ were reduced compared with nontargeting shRNA controls, the responses were significantly different from those with $\mathrm{H}_{2} \mathrm{O}_{2}$ treatment, and clearly showed that the prostanoid signaling pathway was intact (Figure 6c). Western blot analysis confirmed the expression of the MRP4 protein in NHBE cultures from three lung donors (Figure 6e), and a comparison with actin content suggested variable expression levels between individual donors.

The $\mathrm{H}_{2} \mathrm{O}_{2}$-induced release of $\mathrm{PGE}_{2}$ was confirmed by measuring $\mathrm{PGE}_{2}$ levels (see the online supplement for $\mathrm{PGE}_{2}$ assay methods) before and after the exposure of NHBE cells to 300 $\mu \mathrm{M} \mathrm{H}_{2} \mathrm{O}_{2}$ (Figure E3). $\mathrm{H}_{2} \mathrm{O}_{2}$ induced a significant increase in the release of $\mathrm{PGE}_{2}$ (Figure E3a). This increase was inhibited by the COX-2 inhibitor ns398, as well as the MRP inhibitor MK571 (Figure E3b).

Western blots demonstrated that EP1, EP4, and MRP4 were expressed in redifferentiated NHBE cells, but that different amounts of these proteins were expressed in different donor cultures when normalized to actin. Because different individual lung donor cultures also showed variability in the magnitude of the $\mathrm{I}_{\mathrm{SC}}$ response to $\mathrm{H}_{2} \mathrm{O}_{2}$, the relative amounts of EP1, EP4, MRP4, and CFTR expression could be responsible for these differences. Triplicate cultures of fully differentiated NHBE cultures from five lung donors were assayed for $\mathrm{I}_{\mathrm{SC}}$ changes in response to $\mathrm{H}_{2} \mathrm{O}_{2}$, and then individual donor cultures were pooled and extracted for protein and mRNA. EP4 and MRP4 expressions were assessed using both quantitative PCR and Western blots (Figure E4). CFTR and EP1 expression levels were measured only by quantitative PCR (Figures E4e and E4f) because the EP1 receptor is present in two forms (Figure 5), and levels of CFTR in NHBE cells require immunoprecipitation to concentrate the protein (thus Western blots cannot be used for quantitative comparisons). EP4 mRNA and protein levels, as well as EP1 mRNA, showed no correlation with the $\mathrm{I}_{\mathrm{SC}}$. Higher MRP4 (protein in particular) and CFTR expression appeared to correlate with higher $\mathrm{H}_{2} \mathrm{O}_{2}$-stimulated anion currents (Figures E4a, E4b, and E4f), suggesting that levels of EP1 and EP4 were not limiting. On the other hand, CFTR and MRP4 levels may explain the variations seen between donor cultures.

\section{DISCUSSION}

The data presented here support a novel mechanistic pathway in fully differentiated airway epithelia by which $\mathrm{H}_{2} \mathrm{O}_{2}$ stimulates CFTR channel activity via prostanoid synthesis, followed by release through MRP4 and the activation of EP1 and EP4 receptors, in turn activating CFTR (Figure 7). Several new findings on the $\mathrm{H}_{2} \mathrm{O}_{2}$-mediated activation of CFTR are presented in this study, namely, the importance of MRP4 in $\mathrm{H}_{2} \mathrm{O}_{2}$-induced $\mathrm{I}_{\mathrm{SC}}$ increases, the recognition that MRP4 and CFTR seem to comprise the ratelimiting steps in this activation cascade, and the finding that EP1 receptors play a definitive role, because this receptor was not previously described in airway epithelial cells. Finally, we not only show that $\mathrm{H}_{2} \mathrm{O}_{2}$ is present in ASL at higher levels than previously thought and that $\mathrm{H}_{2} \mathrm{O}_{2}$ can increase CFTR activity at these concentrations, but also that $\mathrm{H}_{2} \mathrm{O}_{2}$ inhibits CFTR after a period of time at high concentrations. This inhibitory effect will likely be deleterious for ASL volume and thus mucociliary clearance.

The topic of $\mathrm{H}_{2} \mathrm{O}_{2}$-induced CFTR activation is highly relevant to innate airway host defense. The regulation of ASL volume is a key element in control of mucociliary clearance. A deficit in ASL volume contributes to the pathogenesis of CF (41), and increased ASL volumes increase mucociliary clearance $(42,43)$. ASL volume is controlled in part by anion secretion and the corresponding movement of $\mathrm{Na}^{+}$and $\mathrm{K}^{+}$to and from the mucosal surface $(1,44)$. CFTR channel activity is essential for the regulation of this process. Therefore, the concentration-dependent effects of $\mathrm{H}_{2} \mathrm{O}_{2}$ on CFTR activity will 


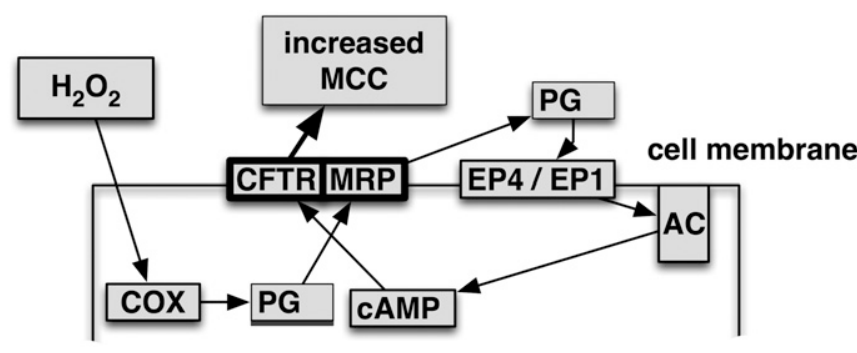

Figure 7. Model for $\mathrm{H}_{2} \mathrm{O}_{2}$ activation of anion secretion by airway epithelia. $\mathrm{H}_{2} \mathrm{O}_{2}$ is proposed to activate cyclooxygenase (COX) to synthesize prostanoids (PG). After release from the cell via MRP4 (MRP), that is, the first rate-limiting step (bold outline), prostanoids activate their $\mathrm{G}$-protein receptors ( $\operatorname{Pr} \mathrm{R}$ ) and signal to adenylyl cyclase to activate the cyclic adenosine monophosphate (CAMP) pathway leading to increased CFTR activity, the second rate-limiting step (bold outline), and increased mucociliary clearance (MCC).

lead to increased ASL and increased mucociliary clearance at low $\mathrm{H}_{2} \mathrm{O}_{2}$ concentrations. High $\mathrm{H}_{2} \mathrm{O}_{2}$ concentrations only transiently increase CFTR activity and then block $\mathrm{Cl}^{-}$exit through CFTR, a situation that could be detrimental for mucociliary clearance and lead to a CF-like airway phenotype.

Previous studies examined the effects of $\mathrm{H}_{2} \mathrm{O}_{2}$ on anion secretion in the airway cell lines Calu-3 $(15,16)$ and $16 \mathrm{HBE} 14 \mathrm{o}-$, and in human nasal epithelia (25). These reports variously showed $\left[\mathrm{H}_{2} \mathrm{O}_{2}\right]$-dependent sustained responses in Calu-3 cells (15) or transient changes in Calu-3 cells, $16 \mathrm{HBE} 14 \mathrm{o}-$ cells, and human nasal epithelial cells $(16,25)$, although the responses in human nasal epithelial cells were ascribed to the effects of hydroxyl radicals (25). NHBE cells, redifferentiated at the ALI, display both sustained and transient responses in an $\left[\mathrm{H}_{2} \mathrm{O}_{2}\right]-$ dependent fashion. However, hydroxyl radicals did not appear to play a role in the effects of $\mathrm{H}_{2} \mathrm{O}_{2}$ on NHBE cells. Furthermore, isoprostanes have been reported to stimulate CFTR activity in cell lines (19), but the inhibition of $\mathrm{H}_{2} \mathrm{O}_{2}$-induced CFTR currents by COX inhibitors in NHBE cells suggests that isoprostanes, which are directly generated by $\mathrm{H}_{2} \mathrm{O}_{2}$ exposure, were not responsible for the observed effects in fully differentiated airway epithelial cells.

We propose a novel role for MRP4 in $\mathrm{H}_{2} \mathrm{O}_{2}$-induced CFTR activation. MRP4 was previously suggested to transport cAMP, and a decrease in MRP4 activity was suggested to lead to an increase in CFTR activity, attributable to the increased availability of cAMP (40). In our NHBE cells, however, MRP4 down-regulation via shRNA did not lead to a higher, forskolinstimulated CFTR response. Instead, forskolin stimulation was reduced. Because MRP4 can interact with CFTR (40), these results may have been a consequence of disrupting the CFTR interactome $(45,46)$. However, low levels of CFTR expression in fully differentiated NHBE cells prevented the reproducible confirmation that MRP4-CFTR interactions occurred.

Duox actively produces $\mathrm{H}_{2} \mathrm{O}_{2}$ in response to increased intracellular $\left[\mathrm{Ca}^{2+}\right](8,47)$. At lower concentrations, the $\mathrm{H}_{2} \mathrm{O}_{2}$ stimulation of CFTR to increase mucociliary clearance occurs concomitantly with increases in $\mathrm{CBF}(2)$ through $\mathrm{Ca}^{2+}$-mediated and cAMP-mediated stimulation. In addition, mucins are also likely secreted through a $\mathrm{Ca}^{2+}$-mediated mechanism (48). It is interesting to speculate that $\mathrm{H}_{2} \mathrm{O}_{2}$ production by epithelial cells contributes to the normal ASL volume increases that accompany the $\mathrm{Ca}^{2+}$-mediated stimulation of $\mathrm{CBF}$ and mucin secretions in the airways. Conversely, when $\mathrm{H}_{2} \mathrm{O}_{2}$ is chronically elevated to high levels, as seen in various airway pathologies (49), the effects of $\mathrm{H}_{2} \mathrm{O}_{2}$ may be deleterious to mucociliary clearance through CFTR inhibition.
In conclusion, our experiments suggest a novel model for $\mathrm{H}_{2} \mathrm{O}_{2}$-stimulated CFTR activity that operates through the activation of COX to synthesize prostanoids, which in turn are released from the cell through MRP4 and bind to their cognate receptors, including EP1 and EP4. Prostanoid receptor-mediated intracellular signaling then activates adenylyl cyclases to increase cAMP levels, and in turn increase CFTR channel activity.

Author disclosures are available with the text of this article at www.atsjournals.org.

Acknowledgments: The authors acknowledge the excellent technical assistance of Nathalie Schmid-Baumlin and Luis Ugalde.

\section{References}

1. Boucher RC. Cystic fibrosis: a disease of vulnerability to airway surface dehydration. Trends Mol Med 2007;13:231-240.

2. Salathe M. Regulation of mammalian ciliary beating. Annu Rev Physiol 2007;69:401-422.

3. Huang P, Gilmore E, Kultgen P, Barnes P, Milgram S, Stutts MJ. Local regulation of cystic fibrosis transmembrane regulator and epithelial sodium channel in airway epithelium. Proc Am Thorac Soc 2004;1: 33-37.

4. Schmid A, Bai G, Schmid N, Zaccolo M, Ostrowski LE, Conner GE, Fregien N, Salathe M. Real-time analysis of cAMP-mediated regulation of ciliary motility in single primary human airway epithelial cells. J Cell Sci 2006;119:4176-4186.

5. Fischer H. Mechanisms and function of Duox in epithelia of the lung. Antioxid Redox Signal 2009;11:2453-2465.

6. Moskwa P, Lorentzen D, Excoffon KJ, Zabner J, McCray PB Jr, Nauseef WM, Dupuy C, Bánfi B. A novel host defense system of airways is defective in cystic fibrosis. Am J Respir Crit Care Med 2007; 175:174-183.

7. Wijkstrom-Frei C, El-Chemaly S, Ali-Rachedi R, Gerson C, Cobas MA, Forteza R, Salathe M, Conner GE. Lactoperoxidase and human airway host defense. Am J Respir Cell Mol Biol 2003;29:206-212.

8. Forteza R, Salathe M, Miot F, Forteza R, Conner GE. Regulated hydrogen peroxide production by Duox in human airway epithelial cells. Am J Respir Cell Mol Biol 2005;32:462-469.

9. Conner GE, Wijkstrom-Frei C, Randell SH, Fernandez VE, Salathe M. The lactoperoxidase system links anion transport to host defense in cystic fibrosis. FEBS Lett 2007;581:271-278.

10. Gattas MV, Forteza R, Fragoso MA, Fregien N, Salas P, Salathe M, Conner GE. Oxidative epithelial host defense is regulated by infectious and inflammatory stimuli. Free Radic Biol Med 2009;47:1450-1458.

11. Harper RW, Xu C, Eiserich JP, Chen Y, Kao CY, Thai P, Setiadi H, Wu R. Differential regulation of dual NADPH oxidases/peroxidases, Duox1 and Duox2, by Th1 and Th2 cytokines in respiratory tract epithelium. FEBS Lett 2005;579:4911-4917.

12. Harper RW, Xu C, McManus M, Heidersbach A, Eiserich JP. Duox2 exhibits potent heme peroxidase activity in human respiratory tract epithelium. FEBS Lett 2006;580:5150-5154.

13. Boots AW, Hristova M, Kasahara DI, Haenen GR, Bast A, van der Vliet A. ATP-mediated activation of the NADPH oxidase Duox1 mediates airway epithelial responses to bacterial stimuli. J Biol Chem 2009;284: 17858-17867.

14. Rada B, Leto TL. Characterization of hydrogen peroxide production by Duox in bronchial epithelial cells exposed to Pseudomonas aeruginosa. FEBS Lett 2010;584:917-922.

15. Cowley EA, Linsdell P. Oxidant stress stimulates anion secretion from the human airway epithelial cell line Calu-3: implications for cystic fibrosis lung disease. J Physiol 2002;543:201-209.

16. Ohashi T, Ito Y, Matsuno T, Sato S, Shimokata K, Kume H. Paradoxical effects of hydrogen peroxide on human airway anion secretion. J Pharmacol Exp Ther 2006;318:296-303.

17. Mall M, Wissner A, Schreiber R, Kuehr J, Seydewitz HH, Brandis M, Greger R, Kunzelmann K. Role of K(V)LQT1 in cyclic adenosine monophosphate-mediated $\mathrm{Cl}(-)$ secretion in human airway epithelia. Am J Respir Cell Mol Biol 2000;23:283-289.

18. Cowley EA, Linsdell P. Characterization of basolateral $\mathrm{K}^{+}$channels underlying anion secretion in the human airway cell line Calu-3. J Physiol 2002:538:747-757. 
19. Joy AP, Cowley EA. 8-iso- $\mathrm{PGE}_{2}$ stimulates anion efflux from airway epithelial cells via the EP4 prostanoid receptor. Am J Respir Cell Mol Biol 2008;38:143-152.

20. Seto V, Hirota C, Hirota S, Janssen LJ. E-ring isoprostanes stimulate a $\mathrm{Cl}$ conductance in airway epithelium via prostaglandin $\mathrm{E}_{2}$-selective prostanoid receptors. Am J Respir Cell Mol Biol 2008;38:88-94.

21. Bernacki SH, Nelson AL, Abdullah L, Sheehan JK, Harris A, Davis CW, Randell SH. Mucin gene expression during differentiation of human airway epithelia in vitro: Muc4 and Muc5B are strongly induced. Am J Respir Cell Mol Biol 1999;20:595-604.

22. Nlend MC, Bookman RJ, Conner GE, Salathe M. Regulator of G-protein signaling protein 2 modulates purinergic calcium and ciliary beat frequency responses in airway epithelia. Am J Respir Cell Mol Biol 2002;27:436-445.

23. Matsui H, Grubb BR, Tarran R, Randell SH, Gatzy JT, Davis CW, Boucher RC. Evidence for periciliary liquid layer depletion, not abnormal ion composition, in the pathogenesis of cystic fibrosis airways disease. Cell 1998;95:1005-1015.

24. Harvey PR, Tarran R, Garoff S, Myerburg MM. Measurement of the airway surface liquid volume with simple light refraction microscopy. Am J Respir Cell Mol Biol 2011;45:592-599.

25. Dazy AC, Auger F, Bailbe D, Blouquit S, Lombet A, Marano F. The toxicity of $\mathrm{H}_{2} \mathrm{O}_{2}$ on the ionic homeostasis of airway epithelial cells in vitro. Toxicol In Vitro 2003;17:575-580.

26. Pezzulo AA, Starner TD, Scheetz TE, Traver GL, Tilley AE, Harvey BG, Crystal RG, McCray PB Jr, Zabner J. The air-liquid interface and use of primary cell cultures are important to recapitulate the transcriptional profile of in vivo airway epithelia. Am J Physiol Lung Cell Mol Physiol 2011;300:L25-L31.

27. Hemler ME, Cook HW, Lands WE. Prostaglandin biosynthesis can be triggered by lipid peroxides. Arch Biochem Biophys 1979;193:340-345.

28. Brenneis C, Maier TJ, Schmidt R, Hofacker A, Zulauf L, Jakobsson PJ, Scholich K, Geisslinger G. Inhibition of prostaglandin $\mathrm{E}_{2}$ synthesis by SC-560 is independent of cyclooxygenase 1 inhibition. FASEB J 2006; 20:1352-1360.

29. Jones CL, Li T, Cowley EA. The prostaglandin $\mathrm{E}_{2}$ Type 4 receptor participates in the response to acute oxidant stress in airway epithelial cells. J Pharmacol Exp Ther 2012;341:552-563.

30. Lawrence RA, Jones RL, Wilson NH. Characterization of receptors involved in the direct and indirect actions of prostaglandins $\mathrm{E}$ and $\mathrm{I}$ on the guinea-pig ileum. Br J Pharmacol 1992;105:271-278.

31. Perreira M, Jiang JK, Klutz AM, Gao ZG, Shainberg A, Lu C, Thomas CJ, Jacobson KA. "Reversine" and its 2-substituted adenine derivatives as potent and selective A3 adenosine receptor antagonists. J Med Chem 2005;48:4910-4918.

32. Clarke DL, Belvisi MG, Smith SJ, Hardaker E, Yacoub MH, Meja KK, Newton R, Slater DM, Giembycz MA. Prostanoid receptor expression by human airway smooth muscle cells and regulation of the secretion of granulocyte colony-stimulating factor. Am J Physiol Lung Cell Mol Physiol 2005;288:L238-L250.

33. Matlhagela K, Taub M. Involvement of EP1 and EP2 receptors in the regulation of the Na,K-ATPase by prostaglandins in MDCK cells. Prostaglandins Other Lipid Mediat 2006;79:101-113.

34. Rutkai I, Feher A, Erdei N, Henrion D, Papp Z, Edes I, Koller A, Kaley $\mathrm{G}$, Bagi Z. Activation of prostaglandin E2 EP1 receptor increases arteriolar tone and blood pressure in mice with Type 2 diabetes. Cardiovasc Res 2009;83:148-154.

35. Tang CH, Yang RS, Fu WM. Prostaglandin E2 stimulates fibronectin expression through EP1 receptor, phospholipase $\mathrm{C}$, protein kinase Calpha, and c-Src pathway in primary cultured rat osteoblasts. $J$ Biol Chem 2005;280:22907-22916.

36. Billot X, Chateauneuf A, Chauret N, Denis D, Greig G, Mathieu MC Metters KM, Slipetz DM, Young RN. Discovery of a potent and selective agonist of the prostaglandin EP4 receptor. Bioorg Med Chem Lett 2003;13:1129-1132.

37. Jones RL, Giembycz MA, Woodward DF. Prostanoid receptor antagonists: development strategies and therapeutic applications. $\mathrm{Br}$ J Pharmacol 2009;158:104-145.

38. Abramovitz M, Adam M, Boie Y, Carrière M, Denis D, Godbout C, Lamontagne S, Rochette C, Sawyer N, Tremblay NM, et al. The utilization of recombinant prostanoid receptors to determine the affinities and selectivities of prostaglandins and related analogs. Biochim Biophys Acta 2000;1483:285-293.

39. Reid G, Wielinga P, Zelcer N, De Haas M, Van Deemter L, Wijnholds J, Balzarini J, Borst P. Characterization of the transport of nucleoside analog drugs by the human multidrug resistance proteins MRP4 and MRP5. Mol Pharmacol 2003;63:1094-1103.

40. Li C, Krishnamurthy PC, Penmatsa H, Marrs KL, Wang XQ, Zaccolo M, Jalink K, Li M, Nelson DJ, Schuetz JD, et al. Spatiotemporal coupling of cAMP transporter to CFTR chloride channel function in the gut epithelia. Cell 2007;131:940-951.

41. Boucher RC. Airway surface dehydration in cystic fibrosis: pathogenesis and therapy. Annu Rev Med 2007;58:157-170.

42. Button B, Picher M, Boucher RC. Differential effects of cyclic and constant stress on ATP release and mucociliary transport by human airway epithelia. J Physiol 2007;580:577-592.

43. Gray T, Coakley R, Hirsh A, Thornton D, Kirkham S, Koo JS, Burch L, Boucher R, Nettesheim P. Regulation of MUC5AC mucin secretion and airway surface liquid metabolism by IL-1beta in human bronchial epithelia. Am J Physiol Lung Cell Mol Physiol 2004;286: L320-L330.

44. Manzanares D, Gonzalez C, Ivonnet P, Chen RS, Valencia-Gattas M, Conner GE, Larsson HP, Salathe M. Functional apical large conductance, $\mathrm{Ca}^{2+}$ -activated, and voltage-dependent $\mathrm{K}^{+}$channels are required for maintenance of airway surface liquid volume. J Biol Chem 2011;286:19830-19839.

45. Li C, Naren AP. Analysis of CFTR interactome in the macromolecular complexes. Methods Mol Biol 2011;741:255-270.

46. Li C, Naren AP. CFTR chloride channel in the apical compartments: spatiotemporal coupling to its interacting partners. Integr Biol (Camb) 2010;2:161-177.

47. Ameziane-El-Hassani R, Morand S, Boucher JL, Frapart YM, Apostolou D, Agnandji D, Gnidehou S, Ohayon R, Noël-Hudson MS, Francon J, et al. Dual oxidase-2 has an intrinsic $\mathrm{Ca}^{2+}$-dependent $\mathrm{H}_{2} \mathrm{O}_{2}$-generating activity. J Biol Chem 2005;280:30046-30054.

48. Okada SF, Zhang L, Kreda SM, Abdullah LH, Davis CW, Pickles RJ, Lazarowski ER, Boucher RC. Coupled nucleotide and mucin hypersecretion from goblet-cell metaplastic human airway epithelium. Am J Respir Cell Mol Biol 2011;45;253-260.

49. Rahman I, Biswas SK, Kode A. Oxidant and antioxidant balance in the airways and airway diseases. Eur J Pharmacol 2006;533:222-239. 